\title{
Eating Pattern and Eating Behavior during Covid-19 Pandemic: Survey on Adults who Work from Home
}

\author{
Lucky Ade Sessiani ${ }^{*}$, Dwi Hartanti ${ }^{1}$ \\ ${ }^{1}$ Program Studi Psikologi Universitas Islam Negeri Walisongo \\ *lucky_sessiani@walisongo.ac.id
}

\begin{abstract}
Covid-19 pandemic impacts many changes in daily life, either in health, social, economic, and psychological context. People will be most likely to change the way they live their life every day, including in eating and working. This research aims to describe empirically how was the eating pattern and eating behavior on adults who work from home (WFH) during Covid-19 pandemic. Instruments used in this research were The Eating Pattern Questionnaire and The Eating Behavior Questionnaire, adapted from The Adult Eating Behavior Questionnaire (He, Jinbo, et.al., 2019). Total of 338 respondents (age mean $=35,13$ years old; $69.8 \%$ female) from various professional backgrounds across Indonesia had completed the questionnaires. Results based on descriptive statistical analysis implied most of respondents had experience changes in eating pattern while WFH, such as: more food consumption, increased snack time, less consumption of fruit and vegetables, and less physical exercise. Changes in eating behavior, namely: 1) enjoy meal time more; 2) more excited to try new variants of food; 3) feel more uncomfortable for delayed meal-time; 4) get hungry more easily; and 5) think more about food when not busy. This research sets the foundation for regulation or intervention strategy in healthy eating behavior as a notable indicator for either nutritional and mental health status.
\end{abstract}

Keywords: Eating Pattern, Eating Behavior, Work from Home, Covid-19 Pandemic

\section{Introduction}

Covid-19 pandemic has had been and still continued to be a global concern and crisis since it first emerged in 2019. Coronavirus disease caused by Severe Acute Respiratory Syndrome Coronavirus-2 (SARS-CoV-2). It is infectious and will caused mild to moderate respiratory illness, serious illness if co- $^{-}$ concurring with other disease, or even death. Therefore, preventive strategy is the best way to protect ourselves and others from the spread and transmission of the virus. WHO suggests health protocols regarding especially on personal hygiene, physical distancing, and staying at home to avoid meeting large numbers of people (WHO, 2021).

Indonesia has undergone to several Covid-19 outbreaks. Government applied regulation at some levels responding urges to slower down the spread and transmission of the virus, while also focusing on the economic. Since the regulations followed by restrictions (social curfews even semi-lockdown), stay-athome became mandatory. Work from Home (WFH) is acclaimed as the most reasonable way to preserve work-health-life balance during the pandemic (Mungkasa, 2020; Alifah, 2021). Despite the benefits, changes in the working system from the traditional way into telecommuting may be challenging. A number of researches have investigated the impacts of WFH in behavioral changes. The flexible working time of WFH requires more adaptation and often result in excessive working hours and difficulty to balance between professional and domestic tasks (Mungkasa, 2020; Fukumura, YE., et.al., 2021; Jenkins \& Smith, 2021; Karl, Peluchette, \& Aghakhani, 2021). Difficulty to achieve balance in WFH may cause stress and conflicts (Alifah, 2021).

Stress, fear, and worry are normal emotional responses when it comes to perceive real lifethreatening situation, as well as when we are faced with uncertain or unknown circumstances. Therefore, it is normal if people are experiencing stress in the context of the COVID-19 pandemic. Significant changes in daily lives create restriction and forced people to face with new realities of working from home, temporary unemployment, home-schooling of children, and lack of physical contact with other family members, friends and colleagues. These changes are undeniably affecting mental health (WHO, 2021). 
Stress as a result of the adaptation process to uncertain conditions, can trigger changes in eating behavior. Several research results show that the impact of stress due to the Covid-19 pandemic affects changes in eating patterns and behavior (Darmaputra, 2021; Breiner, Miller, \& Hormes, 2021). Anxiety, stress, and the desire to be healthy and avoid viruses encourage individuals to change eating patterns and behavior (Akbar and Aidha, 2020; Utama, 2020).

Eating behaviors are a complex consists of physiological, psychological, social, and genetic factors that affect meal timing, the quantity of food intake, food preference, and food selection. The scope involves food preferences, pathological eating behaviors and eating disorders, meal size, and meal selection. The term "eating behaviors" is very broad and commonly used in relation to obesity, dieting, healthy eating, food selection, or disordered eating. Generally, eating behavior describes any kind of behavior or cognitive processes related to eating. The focus is on the attitudes or values connected with different types of eating behaviors, such as whether the eating is seen as wanted or unwanted, or healthy or unhealthy (Smahel, D., et.al., 2018).

Story, Neumark-Sztainer, and French (in Smahel, D., et.al., 2018) describe four factors affecting eating behaviors: (1) individual influences, including psychosocial factors, such as attitudes, beliefs, and knowledge; biological factors, such as hunger; and behavioral factors, such patterns regulation while eating meal and snacks; (2) social environmental influences, such as the impact of family, school, and peer networks. (3) physical environmental influences on accessibility and availability of food, such as accessible shops, restaurants, fast foods, and other food-related stores. (4) Macrosystem societal influences, which play an indirect but still important role in eating behavior and include social and cultural norms around eating, impact of media and advertisements, or local and state laws concerning food.

Eating behavior is a normal behavior associated to eating habits, selecting foods, culinary preparations and quantities of food ingestion (Kabir et al., 2018). Dietary or eating behavior plays important role in affecting future health. Consuming nutrient-poor foods, skipping/delaying meal time, and a lack of appropriate diet are considered unhealthy eating habits and therefore may caused several health problems and nutritional deficiencies. On the other hand, a well-planned healthy diet and the intake of nutritious food can contribute to physical and mental well-being (Ferreira-Pego, et.al., 2020)

Current recommendations for healthy diet in adults consist of balanced and varied menu, which is high in fruit and vegetables, complex carbohydrates, and low in fat. Healthy eating is considered important as it impacts on health in two main ways. First, a healthy diet can be protective against the development of illness, while an unhealthy diet may contribute towards disease. Second, a healthy diet can help manage or treat an illness once a diagnosis has been made. Unfortunately, one large-scale survey in the UK (Food Standards Agency and Department of Health, 2000-2001) reported that approximately $86 \%$ of adults surveyed ate less than the recommended five servings of fruits and vegetables a day. Adult diets were also found to be too high in sugar, salt, and alcohol and deficient in iron and vitamin D, and therefore not meeting the food standards (Ogden, J., 2010). The study on medical workers in Indonesia conducted by Darmaputra (2021) showed similar condition. The average consumption and frequency of main meal consumptions of medical workers were not in accordance with the Food Guidelines recommended by the Ministry of Health of the Republic of Indonesia. Respondents also reported having an increasing workload (60.4\%) and showed changes in their eating habits when they were under various stresses.

Eating is one of the ways that individuals do to cope with stress (Wijayanti, Margawati, Wijayanti, 2019; Ferreira-Pego, et.al., 2020). When stressed, the body will release several hormones that affect eating behavior and nutrient intake so that it can increase the risk of obesity (Wijayanti, Margawati, Wijayanti, 2019; Widiantini and Tafal, 2014). In addition, the WFH system that is held online tends to be sedentary (less movement), thus, if combined with unhealthy eating patterns and behaviors, it will lead to various risks.

People often eat, not just because they are hungry, but for other reasons as well. Whatever the specific triggers, many aspects of food consumption are emotion-related. Eating may relieve negative affect, assert control, enable to cope with loneliness, or demonstrate group solidarity. Eating decisions examined here include emotional, restrained, and external eating as they relate to the role of personality (Goodboy \& Booth Butterfield, 2007). Evidences also showed that eating is emotion-related when it comes to body image. Research in Indonesian college students show result that obtaining attractive body shape was the most voted reason of dieting, while cutting eating frequency was the most frequent dieting method. This study implied that body dissatisfaction was followed by poor dietary behaviour (Meiliana, 
Valentina, Retnaningsih, 2018). Similar research in Chinese college students was also implied that students who were dissatisfied with their bodies or overestimated their body weight showed a higher tendency toward high restrained eating (Yong, et.al., 2021).

Emotional eating is one examples of unhealthy eating behavior that can affect a person's nutritional intake adequacy. When experiencing emotional eating, people tend to choose foods that are high in energy and fat. If this habit is continuously carried out, it will cause significant weight gain that can become overweight even obese. On the other hand, there are some people who, when under stress, eat little or no food at all. If this happens in the long term, it will affect body weight. Uncontrolled weight will affect the state of nutritional status (Wijayanti, Margawati, Wijayanti, 2019 ; He, J., et.al., 2019 ) .

This study will measure eating patterns according to the Balanced Nutrition Guideline regulated by the Ministry of Health of the Republic of Indonesia (2014), including:

a. Be grateful and enjoy a variety of foods

b. Eat lots of vegetables and enough fruits

c. Get used to eat side dishes that contain high protein

d. Get used to eat a variety of staple foods

e. Limit consumption of sweet, salty and fatty foods

f. Get used to having breakfast before work

g. Drink enough and safe water

h. Get used to reading labels on food packaging

i. Make it a habit to wash your hands with soap and clean running water

j. Exercise regularly and maintain a normal weight

Eating behavior on adults measured based on the aspects of The Adult Eating Behavior Questionnaire (AEBQ). The AEBQ was constructed to assess eight adult appetitive traits and to examine the relations between appetitive traits and body mass index (BMI). The AEBQ measured four foodapproach traits (i.e., Hunger, Food Responsiveness, Emotional Overeating, and Enjoyment of Food), and four food-avoidance traits (Satiety Responsiveness, Emotional Undereating, Food Fussiness, and Slowness in Eating) (Hunot et al., 2016). Two studies involving adult samples from the United Kingdom and Australia, showed the food-approach traits (with the exception of Hunger) were positively correlated with BMI, whereas the food-avoidance traits were negatively correlated with BMI (Hunot et al., 2016; Mallan et al., 2017). Since its common use on clinical settings, evidences regarding the AEBQ in nonclinical setting and Asian or non-Western societies are relatively scarce.

This study will examine four food-approach traits from the AEBQ, based on the previous research conducted in China by He, et.al (2019). By far, this was the first research which used the aspects of AEBQ to examine eating behavior during pandemic in Indonesia.

The aim of this study was to describe the eating patterns and behaviors of adults who work from home (WFH) during the Covid-19 pandemic. This study used an online survey data collection method via google form. Data collection was carried out during the first one-month period since the Indonesian government enacted the policy to work from home. The benefits of this research namely to: (1) provide information to the public about eating patterns and behaviors that support physical and mental health, (2) Provide information to the public about the changes in patterns and eating behavior that occurred when performing work from home (WFH) during Covid-19 pandemic.

\section{Methods}

This study used quantitative method based on an online survey, conducted during the first month since Indonesian government declared Covid-19 pandemic emergency situation. The selection of this specific time period was considering the level of adaptation process toward WFH system. Respondents may still be struggling to adjust on new work order and improve new behaviors, and therefore at their peak of learning process. The survey was conducted from April 26 to April 30, 2020, on Google Form link (https://forms.gle/yMephFrxqwivuCvN7) shared via e-mail and Whatsapp group platform

Participation in the survey was voluntary, targetted the working adults population (age 21-65 years old). This study used non-probability sampling method. At the beginning of questionnaire, each participant was informed on the study objectives and statement of informed consent.

The survey consist two sections of questionnaire: first section assessed eating pattern, while the second section assessed eating behavior. The questionnaire comprised different type of questions: 1) Socio-demographics (sex, age, and profession); 2) Section 1: The Eating Pattern Questionnaire consist of 
8 questions based on the Balanced Nutrition Guideline by Ministry of Health of the Republic of Indonesia (2014); 3) Section 2: The Eating Behavior Quaestionnaires consist 10 questions represent the four foodapproach traits (He, et.al., 2019).

Valid total responses were 338, downloaded from Google Form to perform analysis in SPSS (Statistics Package for Social Sciences) version 25.0. Descriptive statistics analysis was performed to measure frequencies, means, and percentages based on each item responses.

\section{Results}

The results of this survey revealed how eating pattern and eating behavior are affected by the WFH situation, during the first month of Covid-19 pandemic in Indonesia. This section will first present sociodemographic characteristics of the survey participants (3.1), descriptive statistics on eating pattern (3.2), and eating behavior (3.3).

\section{Socio-demographic characteristics}

As revealed in Table 1, the number of female respondents was 236 or $69.8 \%$ and 102 or $30.2 \%$ were male.

Table 1. Gender characteristics of study participants $(\mathrm{n}=338)$

\begin{tabular}{llllll}
\hline & Frequency & Percent & Valid Percent & Cumulative Percent \\
\hline Valid & Wo-man & 236 & 69.8 & 69.8 & 69.8 \\
& Man & 102 & 30.2 & 30.2 & 100.0 \\
& Total & 338 & 100.0 & 100.0 & \\
\hline
\end{tabular}

Table 2 showed the age characteristic of participants. It revealed that most respondents were in the range between 27-36 years old.

Table 2. Age characteristics of study participants $(n=338)$

\begin{tabular}{lllll}
\hline Age & Frequency & Percent & Valid Percent & Cumulative Percent \\
\hline 21 & 1 & .3 & .3 & .6 \\
22 & 1 & .3 & .3 & .9 \\
23 & 9 & 2.7 & 2.7 & 3.6 \\
24 & 6 & 1.8 & 1.8 & 5.3 \\
25 & 8 & 2.4 & 2.4 & 7.7 \\
26 & 7 & 2.1 & 2.1 & 9.8 \\
27 & 21 & 6.2 & 6.2 & 16.0 \\
28 & 11 & 3.3 & 3.3 & 19.2 \\
29 & 16 & 4.7 & 4.7 & 24.0 \\
30 & 17 & 5.0 & 5.0 & 29.0 \\
31 & 18 & 5.3 & 5.3 & 34.3 \\
32 & 19 & 5.6 & 5.6 & 39.9 \\
33 & 23 & 6.8 & 6.8 & 46.7 \\
34 & 29 & 8.6 & 8.6 & 55.3 \\
35 & 38 & 11.2 & 11.2 & 66.6 \\
36 & 20 & 5.9 & 5.9 & 72.5 \\
37 & 2 & .6 & .6 & 73.1 \\
38 & 11 & 3.3 & 3.3 & 76.3 \\
39 & 9 & 2.7 & 2.7 & 79.0 \\
40 & 8 & 2.4 & 2.4 & 81.4 \\
41 & 3 & .9 & .9 & 82.2 \\
42 & 5 & 1.5 & 1.5 & 83.7 \\
43 & 4 & 1.2 & 1.2 & 84.9 \\
44 & 4 & .9 & .9 & 85.8 \\
45 & 3 & .6 & 1.5 & 87.3 \\
46 & 5 & .6 & .6 & 87.9 \\
47 & 2 & & .6 & 88.5
\end{tabular}




\begin{tabular}{lllll}
\hline Age & Frequency & Percent & Valid Percent & Cumulative Percent \\
\hline 48 & 6 & 1.8 & 1.8 & 90.2 \\
49 & 4 & 1.2 & 1.2 & 91.4 \\
50 & 8 & 2.4 & 2.4 & 93.8 \\
52 & 3 & .9 & .9 & 94.7 \\
54 & 3 & .9 & .9 & 95.6 \\
55 & 5 & 1.5 & 1.5 & 97.0 \\
57 & 2 & .6 & .6 & 97.6 \\
58 & 1 & .3 & .3 & 97.9 \\
59 & 3 & .9 & .9 & 98.8 \\
60 & 1 & .3 & .3 & 99.1 \\
61 & 1 & .3 & .3 & 99.4 \\
63 & 1 & .3 & .3 & 99.7 \\
65 & 1 & .3 & .3 & 100.0 \\
Total & 338 & 100.0 & 100.0 & \\
\hline
\end{tabular}

From Table 3 we can see that most of respondents (44.4\%) work as employees either in private or state-owned enterprise (BUMN), lecturer (25.1\%), and teacher (17.5\%).

Table 3. Profession (Job) characteristics of study participants ( $=338)$

\begin{tabular}{|c|c|c|c|c|}
\hline & Frequency & Percent & Valid Percent & Cumulative Percent \\
\hline Insurance agent & 1 & .3 & .3 & .3 \\
\hline Architect & 1 & .3 & .3 & .6 \\
\hline Assessor & 1 & .3 & .3 & .9 \\
\hline Medical doctor & 1 & .3 & .3 & 1.2 \\
\hline Lecturer & 85 & 25.1 & 25.1 & 26.3 \\
\hline Entreprenuer & 13 & 3.8 & 3.8 & 30.2 \\
\hline Freelancer & 3 & .9 & .9 & 31.1 \\
\hline Teacher & 59 & 17.5 & 17.5 & 48.5 \\
\hline Business owner & 16 & 4.7 & 4.7 & 53.3 \\
\hline Employee & 150 & 44.4 & 44.4 & 97.6 \\
\hline Consultant & 1 & .3 & .3 & 97.9 \\
\hline Online seller & 1 & .3 & .3 & 98.2 \\
\hline Researcher & 1 & .3 & .3 & 98.5 \\
\hline Writer & 1 & .3 & .3 & 98.8 \\
\hline Civil worker (PNS) & 1 & .3 & .3 & 99.1 \\
\hline Psychologist & 1 & .3 & .3 & 99.4 \\
\hline School psychologist & 1 & .3 & .3 & 99.7 \\
\hline Digital marketer & 1 & .3 & .3 & 100.0 \\
\hline Total & 338 & 100.0 & 100.0 & \\
\hline
\end{tabular}

Eating pattern during WFH in Covid-19 pandemic 
Table 4 below described the responses toward items regarding eating pattern changes during WFH in Covid-19 pandemic.

Table 4. Changes on eating pattern during WFH in Covid-19 pandemic ( $\mathrm{n}=338)$

\begin{tabular}{|c|c|c|c|c|c|}
\hline Item & Options & Frequency & Percent & $\begin{array}{l}\text { Valid } \\
\text { Percent }\end{array}$ & $\begin{array}{l}\text { Cumulative } \\
\text { Percent }\end{array}$ \\
\hline \multirow{4}{*}{$\begin{array}{l}\text { Change in food } \\
\text { consumption }\end{array}$} & No & 127 & 37.6 & 37.6 & 37.6 \\
\hline & $\begin{array}{l}\text { Yes, it become } \\
\text { more }\end{array}$ & 161 & 47.6 & 47.6 & 85.2 \\
\hline & $\begin{array}{l}\text { Yes, it become } \\
\text { less }\end{array}$ & 50 & 14.8 & 14.8 & 100.0 \\
\hline & Total & 338 & 100.0 & 100.0 & \\
\hline \multirow{3}{*}{$\begin{array}{l}\text { Frequency } \\
\text { eating meal }\end{array}$} & 3 times a day & 208 & 61.5 & 61.5 & 61.5 \\
\hline & $>3$ times a day & 130 & 38.5 & 38.5 & 100.0 \\
\hline & Total & 338 & 100.0 & 100.0 & \\
\hline \multirow{4}{*}{$\begin{array}{l}\text { Frequency } \\
\text { eating snacks }\end{array}$} & 1-2 times a day & 240 & 71.0 & 71.0 & 71.0 \\
\hline & $>3$ times a day & 72 & 21.3 & 21.3 & 92.3 \\
\hline & Never & 26 & 7.7 & 7.7 & 100.0 \\
\hline & Total & 338 & 100.0 & 100.0 & \\
\hline \multirow{4}{*}{$\begin{array}{l}\text { Frequency } \\
\text { eating } \\
\text { vegetables }\end{array}$} & $\begin{array}{l}\text { 1-2 times a day or } \\
\text { more }\end{array}$ & 274 & 81.1 & 81.1 & 81.1 \\
\hline & $\begin{array}{l}3 \text { times a day or } \\
\text { more }\end{array}$ & 53 & 15.7 & 15.7 & 96.7 \\
\hline & Never & 11 & 3.3 & 3.3 & 100.0 \\
\hline & Total & 338 & 100.0 & 100.0 & \\
\hline \multirow{4}{*}{$\begin{array}{l}\text { Frequency } \\
\text { eating fruits }\end{array}$} & 1-2 times a day & 280 & 82.8 & 82.8 & 82.8 \\
\hline & $\begin{array}{l}3 \text { times a day or } \\
\text { more }\end{array}$ & 18 & 5.3 & 5.3 & 88.2 \\
\hline & Never & 40 & 11.8 & 11.8 & 100.0 \\
\hline & Total & 338 & 100.0 & 100.0 & \\
\hline \multirow{4}{*}{$\begin{array}{l}\text { Frequency of } \\
\text { doing exercise }\end{array}$} & Rarely/Never & 188 & 55.6 & 55.6 & 55.6 \\
\hline & $\begin{array}{l}\text { Yes, } 1-2 \text { times a } \\
\text { week at least } 30 \\
\text { minutes }\end{array}$ & 113 & 33.4 & 33.4 & 89.1 \\
\hline & $\begin{array}{l}\text { Yes, every day at } \\
\text { least } 30 \text { minutes }\end{array}$ & 37 & 10.9 & 10.9 & 100.0 \\
\hline & Total & 338 & 100.0 & 100.0 & \\
\hline \multirow{4}{*}{$\begin{array}{l}\text { Supplement } \\
\text { intake }\end{array}$} & Never & 96 & 28.4 & 28.4 & 28.4 \\
\hline & $\begin{array}{l}\text { Yes, regularly } \\
\text { every day }\end{array}$ & 65 & 19.2 & 19.2 & 47.6 \\
\hline & $\begin{array}{l}\text { Yes, but not } \\
\text { routine }\end{array}$ & 177 & 52.4 & 52.4 & 100.0 \\
\hline & Total & 338 & 100.0 & 100.0 & \\
\hline \multirow{4}{*}{$\begin{array}{l}\text { Changes } \\
\text { weight }\end{array}$} & No changes & 168 & 49.7 & 49.7 & 49.7 \\
\hline & $\begin{array}{l}\text { Yes, weight tends } \\
\text { to increase }\end{array}$ & 45 & 13.3 & 13.3 & 63.0 \\
\hline & $\begin{array}{l}\text { Yes, weight tends } \\
\text { to decrease }\end{array}$ & 125 & 37.0 & 37.0 & 100.0 \\
\hline & Total & 338 & 100.0 & 100.0 & \\
\hline
\end{tabular}

Table 4 revealed 127 subjects or $37.6 \%$ who answered "no", 161 subjects or $47.6 \%$ answered "yes, it becomes more", and 50 subjects or $14.8 \%$ answered "yes, it becomes less". Most participants felt changes in food consumption, $47.6 \%$ consumed more food while doing WFH.

Moreover, the table showed 208 subjects or $61.5 \%$ answered having meal time 3 times a day and $71 \%$ ate snacks 1-2 times a day. Most participants were also eats vegetables (81.1\%) and fruits (82.8\%) 
for 1-2 times a day. Physical exercise was not seemed to be done regularly, since most of participants (55.6\%) reported rarely or never do exercise at home during pandemic. Immune-boosting intake reported done but not regularly by $52.4 \%$ participants. Due to weight changes, $49.7 \%$ respondents reported not feeling any weigth change, while $37 \%$ of participants felt their weight is decreasing.

\section{Eating behaviour during Covid-19 pandemic}

Result in Table 5 shows responses from the Eating Behavior Questionnaires, on each items represent four food-approach traits. The responses are classified into Very Inappropriate (VI), Inappropriate (I), Appropriate (A), and Very Appropriate (VA). Responses describe in percent (\%).

Table 5. Eating behavior during WFH in Covid-19 pandemic (n=338)

\begin{tabular}{|c|c|c|c|c|c|}
\hline \multirow{2}{*}{$\begin{array}{l}\text { Food-approach } \\
\text { traits }\end{array}$} & \multirow[t]{2}{*}{ Item } & \multicolumn{4}{|c|}{ Percent (\%) } \\
\hline & & VI & I & $\mathrm{A}$ & VA \\
\hline \multirow{2}{*}{$\begin{array}{l}\text { Enjoyment } \\
\text { food }\end{array}$} & I enjoy meal time. & 1.2 & 4.4 & 71.6 & 22.8 \\
\hline & $\begin{array}{l}\text { During WFH, I enjoy trying new kinds } \\
\text { of food. }\end{array}$ & 1.5 & 34.6 & 52.7 & 11.2 \\
\hline \multirow[t]{2}{*}{ Hunger } & $\begin{array}{l}\text { I will feel uncomfortable when I eat } \\
\text { late. }\end{array}$ & 1.8 & 29.3 & 50.6 & 18.3 \\
\hline & I get hungry easily. & 1.5 & 40.2 & 44.7 & 13.6 \\
\hline \multirow{2}{*}{$\begin{array}{l}\text { Food responsive- } \\
\text { ness }\end{array}$} & I think about food when I'm not busy. & 4.4 & 42.6 & 45.3 & 7.7 \\
\hline & $\begin{array}{l}\text { During WFH, I think about food more } \\
\text { often. }\end{array}$ & 4.1 & 46.4 & 41.1 & 8.3 \\
\hline \multirow[t]{4}{*}{$\begin{array}{l}\text { Emotional over- } \\
\text { eating }\end{array}$} & $\begin{array}{l}\text { When things do not go the way I } \\
\text { wanted (not according to plan), I feel } \\
\text { like eating. }\end{array}$ & 8.0 & 58.9 & 29.0 & 4.1 \\
\hline & I eat more when I feel anxious. & 9.5 & 64.2 & 21.0 & 5.3 \\
\hline & When I feel bored, I want to eat. & 4.1 & 42.9 & 43.8 & 9.2 \\
\hline & I eat more when I'm angry. & 9.5 & 67.8 & 18.0 & 4.7 \\
\hline
\end{tabular}

Presentation in the table showed percentage of each item responses. The highest percentage from each favorable item responses (A/Appropriate and VA/Very Appropriate) describe the occurrence of certain eating behavior during WFH. Total percentage of A/Appropriate and VA/Very Appropriate responses on each item may described that participants were experiencing the changes of eating behavior while WFH.

Changes in eating behavior associated with enjoyment of food can be seen from the responses in item "I enjoy meal time" and "I enjoy trying new kinds of food". Most participants $(71.6 \%$ answered appropriate and $22.8 \%$ responded very appropriate $=94.4 \%$ total $)$ responded to be enjoyed meal time more and enjoyed trying new kinds of food (63.9\% total).

The second food-approach traits: hunger, is also the second most favorable item. Most participants reported to feel uncomfortable when eating late $(68.9 \%$ total), and get hungry more easily (58.3\% total). While in food responsiveness trait, most participants reported to think more about food when not busy (53\% total) and often think about food during WFH (49.4\% total).

Most participants reported themselves not experiencing changes in eating behaviors associated with emotional over-eating. A number of $58.9 \%$ participants saw themselves do not feel like wanted to eat when something went out of plan. Participants were also responded not to be more likely trigerred to eat, while having emotional situations. Most participants did not eat more when feeling anxious (64.2\%) and angry $(67.8 \%)$. The only emotional situation that may stimulated the desire to eat was boredom. A total number of $53 \%$ participants responded that they want to eat when feel bored. 


\section{Discussion}

The purpose of this study was to describe the eating patterns and behaviors in adults who work from home (WFH) during the Covid-19 pandemic. The result identified the changes in eating pattern and behavior based on the participants experience while performing WFH during Covid-19 pandemic. Eating pattern was measured via online survey, based on the implementation of Balanced Nutrition Guidelines regulate by Indonesian Ministry of Health. Whilst eating behavior was measured based on four foodapproach traits in the Adult Eating Behavior Questionnaires (AEBQ) previously used in researches by He, et.al (2019), Mallan, et.al (2017), and Hunot, et.al. (2016). By far, this is the first research using the aspects of AEBQ to examine eating behavior during pandemic situation in Indonesia.

This study provided novel insights in identified eating pattern changes of adult performing WFH during Covid-19 pandemic in Indonesia. Result shows that most respondents experienced changes in eating pattern. Evidences of unhealthy eating showed in increased food intake/consumption, frequent snacks intake, low fruit and vegetable intake, and less physical exercise.

Balanced Nutrition Guidelines state that the balance between energy intake and energy expenditure will have an impact on the nutritional status of individuals. Energy intake from food in amounts greater than energy expenditure through physical activity has an effect on weight gain. Energy intake from food in smaller amounts than energy expenditure through physical activity has an effect on weight loss. Meanwhile, energy intake from balanced food with energy expenditure through physical activity will have an effect on ideal body weight conditions (Kemenkes RI, 2014).

The WFH situation definitely has an impact on the activity patterns of the workers. In general, workers tend to be more active when working in the office while WFH makes it decrease because activities are only carried out at home and work is done through online methods. This decreased activity level coupled with increased food intake while at home resulted in weight gain. A total of $47.6 \%$ of respondents experienced an increase in food intake during WFH.

Intake of snacks also increases when individuals do work from home. Snacks that are commonly consumed are fried foods, wafers, and sweet foods and drinks. Sweet foods are foods that contain high calories because they contain a lot of sugar. Sugars are classified as simple carbohydrates composed of the elements carbon, hydrogen, and oxygen. Sugar contains the most energy and contains only a few vitamins and minerals (Wenck, et al. 2000) because sugar is a simple carbohydrate, sugar is easily absorbed by the intestines to be used as energy and converted into glycogen and fat for further storage in the liver and adipose tissue. as a source of energy for the body (Wilson et al., 2000).

Limit consumption of sugar at most in a day is $10 \%$ of the total calories we need. So if the nutritional adequacy rate for adults in a day is $2000 \mathrm{kcal}$, the sugar that can be consumed is around 200 kcal / $4=50$ grams (Kemenkes RI, 2014). Excess consumption of simple carbohydrates will be stored in the form of glycogen and fat which will then lead to overweight and obesity.

The results of this study are in line with Roselly's (2008) research on factors related to obesity in men (40-55 years) at the Directorate General of Zeni TNI-AD (Indonesian Army), it was found that there was a significant relationship between obesity and fat consumption $(p=0.044)$. A multivariate analysis conducted by Koh-Banerjee et. al. (2003) in the United States found that $2 \%$ increase in energy intake from isocaloric trans-fat replacing either fat (polyunsaturated fat) or carbohydrates was significantly associated with an increase in waistline of $0.77 \mathrm{~cm}$ over 9 years. Fat is the body's largest energy reserve. Fat has a savory taste. Fat has a high energy density, so it can cause a positive balance and the excess will be stored in adipose tissue. Increased adipose tissue will increase leptin, so that it has an influence on regulating energy balance and in the end can cause obesity (Margaret, et al. 2000 in Pujiati, 2010).

The fiber intake of the respondents was also less than the dietary recommendations. This is proven by more than $80 \%$ of respondents consume vegetables and fruit only 1-2 servings a day. The recommendation from the Indonesian Ministry of Health regarding the intake of vegetables and fruit is 5-6 servings a day.

Von Eyben (2003) states that increasing the intake of vegetables and fruit reduces the intake of high fat and sugar, while the intervention of reducing fat and sugar has no effect on changes in the intake of vegetables and fruit. Increased consumption of carbohydrates and fiber can increase satiety, and decrease energy and fat intake. Fiber can limit energy intake because it has a low energy density and satiety accelerating effect. When a person consumes food that contains a lot of dietary fiber, then that person will feel full faster. With the presence of dietary fiber, the person will chew longer, and this will stimulate the excretion of saliva and more gastric juices. This excessive secretion will cause the 
stomach to feel full. In addition, in the presence of dietary fiber, the absorption of nutrients (starch, sugar, protein, fat) will be blocked, so that the amount that will be oxidized into energy is reduced (Muchtadi, 2001).

Most of participants (55.6\%) stated themselves rarely or even never performing physical exercise at home. In line with the findings from Breiner, et.al. (2021) research in US, which showed that most people choose not to spend much time to do physical exercise. Lack of physical exercise combined with unhealthy diet (less fiber) will impact on degradation of health status or even obesity (Nurcahyo, 2011). Study by Widiantini and Tafal (2014) found that physical exercise may lower the risk for obesity to 40$60 \%$.

Moreover, findings in eating behaviors also showed notable changes, associated with four foodapproach traits: enjoyment of food, hunger, food-responsiveness, and emotional over-eating (He, et.al, 2019; Mallan, et.al., 2017; Hunot, et.al., 2016). Result indicated that enjoyment of food was the eating behavior mostly changed during the first month of WFH. Notably, a total number of $94.4 \%$ participants enjoyed meal time more, and $63.9 \%$ reported to be enjoyed trying new kinds of food. In line with the research findings from Ben Hassen, et.al., (2021) in Russia which indicates that $89.9 \%$ of the respondents reported that they are not wasting more food than usual since the Covid-19 outbreak. They are also reported to spend more meal time with family and prepared food more frequently.

Digital technology and internet use may also playing its role in increasing the enjoyment of trying new kinds of food (Smahel, et.al., 2018; Ferreira-Pego, et.al., 2020). During Covid-19 pandemic, online food service and delivery were really high on demand. People had no option to enjoy food directly by went to a restaurant due to physical distancing, therefore ordering food online was the best choice. Smahel, et.al (2018) stated that accessibility and availability of food were influential factors toward eating behavior. People become more enjoyed to try more variants of food since it is easier to order by online service. While working from home, people paid less effort to get many kinds of new meals delivered in front of their doors.

In term of hunger, most participants reported to feel uncomfortable when eating late (68.9\% total), and get hungry more easily (58.3\% total). It is to be concluded that working from home was triggered feeling of hunger and need eat more frequent. The lack of social interaction may creates the feeling of loneliness and therefore impacts on desire to eat. As suggested by Herle, et.al (2021) research finding, that loneliness was correlated to stimulate the desire to eat more persistently.

Moreover, qualitative research conducted by Wehling \& Lusher (2019) described how eating food acted as a response to negative emotions effectively, especially when feeling sad or lonely. Food appeared to offer emotional support similar to a close friend, suggesting an unusually close bond and comforting like having a companion. Positive sensations of eating foods outweighed the anticipated negative consequences at that moment negative emotion aroused. This pattern of emotionally-dependency over foods may leads to emotional over-eating behavior.

Many researches had found that emotion or feeling are associated with eating behavior (Wehling \& Lusher, 2019; Devonport, Nicholls, \& Fullerton, 2017; Razolli, et.al., 2017; Dweck, Jenkins, \& Nolan, 2014; Bennet, Greene, \& Barcott, 2013). Feeling of boredom and weary are emotionally-related to overeating behavior. Evidence from this research showed that a total number of $53 \%$ participants responded having desire to eat when feeling bored. Unpleasant feelings or negative emotions such as boredom or anxiety may triggered eating behavior, turning to food as a distraction (Bennet, Greene, \& Barcott, 2013) and seeking comfort from food (Wehling \& Lusher, 2019).

Behavior changes associated to food-responsiveness trait were to think more about food when not busy (reported by 53\% respondents) and often think about food during WFH (reported by $49.4 \%$ respondents). Eating behavior linked with cognitive processes, such as sensation, perception, attention and memory. Study conducted by Bedard, et.al (2020) reported that sensory experiences and memories associated with eating are key dimensions of eating pleasure. People tends to build strong relationship with food once they feel that eating create pleasure. It is more likely for people to think about food more often as a pleasure seeking behavior, especially when the work gets weary or feeling stressed during WFH.

In this research, evidence showed that not all emotion/feeling leads to emotional over eating. Participants reported not triggered to eat more when feeling dissapointed, angry, or anxious. Unlike boredom, participants responded unfavorably to these forms of negative emotions. This findings are irrelevant with evidence from previous research by Fassah \& Retnowati (2014) which conducted to college students in Indonesia, showed that emotional distress leads to unhealthy eating behavior. Dweck, 
Jenkins, \& Nolan (2014) also found that a significant stress leads to emotional eating and sleep deprivation. Razolli, et.al (2017) research finding suggest that stress exposure was having a strong link with binge-eating, which is also a form of impulsive and emotional over-eating behavior.

This study has provided novel evidences in adult's eating pattern and eating behavior during Covid-19 pandemic. Notably, it may applied as reference for future research, to cope with this research limitations. The limitations of this study are as follows: First, dimensions of eating behavior measured in this research was only focusing on food-approach traits, while the original and complete version of the AEBQ also comprised food-avoidance traits (He, et.al, 2019; Mallan, et.al, 2017; and Hunot, et.al., 2016). Further research are suggested to completely measured all of appetitive traits to determine eating behavior more clearly.

Second, data findings are analyzed using basic descriptive analysis. Future research can provide more complex analysis, for example by examining the role of gender differences in eating behavior, or analyze the role of other variables toward eating behavior.

Further research was also needed to describe the occurrence of emotional eating behavior. This research provides evidences on how anger, anxiety and dissapointment were not triggered emotional over-eating. But it is still unclear, whether those emotions may triggered the opposite eating behavior, which is emotional under-eating.

\section{Conclusion}

In sum, this study has fullfilled its purpose to describe the eating patterns and behaviors of adults who work from home (WFH) during the Covid-19 pandemic. It provides evidence on how eating behavior and nutritional intake linked to emotional, cognitive process, and stress-related behavior, while dealing with working situation during crisis.

The present study contributes to the literature on eating pattern and eating behavior especially during Covid-19 pandemic. In addition, this research sets the foundation for regulation or intervention strategy in healthy eating behavior as a notable indicator for either nutritional and mental health status. Based on this research findings, future regulations may focus on intervention or promotion program aim to improve nutritional health behaviors, increase motivation, healthy eating behavior support, and skills to enable people living their life in a physically and mentally healthy way.

\section{Bibliography}

Akbar, D.M, and Aidha, Z. (2020). Perilaku Penerapan Gizi Seimbang Masyarakat Kota Binjai pada Masa Pandemi Covid-19 tahun 2020. Menara Medika, 3 (1), 15-21. https://doi.org/10.31869/mm.v3i1.2193

Alifah, A., (2021). Efek mediasi work-family conflict terhadap stres kerja pada ibu bekerja di rumah selama pandemi covid-19. Jurnal Ekobis : Ekonomi Bisnis \& Manajemen, 11(1), pp.1-16. https://doi.org/10.37932/j.e.v11i1.171

Bédard, A., Lamarche, P. O., Grégoire, L. M., Trudel-Guy, C., Provencher, V., Desroches, S., \& Lemieux, S. (2020). Can eating pleasure be a lever for healthy eating? A systematic scoping review of eating pleasure and its links with dietary behaviors and health. PloS one, 15(12), e0244292. https://doi.org/10.1371/journal.pone.0244292

Ben Hassen, T., El Bilali, H., Allahyari, M., Berjan, S., \& Fotina, O. (2021). Food purchase and eating behavior during the COVID-19 pandemic: A cross-sectional survey of Russian adults. Appetite, 165, 105309. https://doi.org/10.1016/j.appet.2021.105309

Bennett, J., Greene, G., \& Schwartz-Barcott, D. (2013). Perceptions of emotional eating behavior. A qualitative study of college students. Appetite, 60(1), 187-192. https://doi.org/10.1016/j.appet.2012.09.023

Breiner, C., Miller, M., \& Hormes, J. (2021). Changes in eating and exercise behaviors during the COVID-19 pandemic in a community sample: A retrospective report. Eating Behaviors, 42, 101539. https://doi.org/10.1016/j.eatbeh.2021.101539

Darmaputra, Muhammad Shafriedho and Kurniati, Ardesy Melizah and Adnindya, Msy.Rulan (2021) Perilaku Makan Pada Tenaga Medis Di Provinsi Sumatera Selatan Saat Pandemi Covid-19. Undergraduate thesis, Sriwijaya University. http://repository.unsri.ac.id/id/eprint/39921 
Devonport, T. J., Nicholls, W., \& Fullerton, C. (2019). A systematic review of the association between emotions and eating behaviour in normal and overweight adult populations. Journal of health psychology, 24(1), 3-24. https://doi.org/10.1177/1359105317697813

Dweck, J. S., Jenkins, S. M., \& Nolan, L. J. (2014). The role of emotional eating and stress in the influence of short sleep on food consumption. Appetite, 72, 106-113. https://doi.org/10.1016/j.appet.2013.10.001

Fassah, D. R., \& Retnowati, S. (2014). Hubungan Antara Emotional Distress Dengan Perilaku Makan Tidak Sehat Pada Mahasiswa Baru. Jurnal Psikologi, 10 (1), 11-17. file://Users/user/Downloads/11742749-1-SM.pdf

Ferreira-Pêgo, C., Rodrigues, J., Costa, A., \& Sousa, B. (2020). Eating behavior: The influence of age, nutrition knowledge, and Mediterranean diet. Nutrition and Health, 26(4), 303-309. https://doi.org/10.1177/0260106020945076

Fukumura, Y. E., Schott, J. M., Lucas, G. M., Becerik-Gerber, B., \& Roll, S. C. (2021). Negotiating Time and Space When Working from Home: Experiences During COVID-19. OTJR: Occupation, Participation and Health. https://doi.org/10.1177/15394492211033830

Goodboy, A.K., Booth-Butterfield, M., (2007). Affective orientation and eating behavior: two studies of emotional, restrained, and external eating decisions 'and external eating decisions. Psychological Reports, 2007, 101, 913-919. https://doi.org/10.2466/PR0.101.7.913-919

He, J., Sun, S., Zickgraf, H. F., Ellis, J. M., \& Fan, X. (2019). Assessing Appetitive Traits Among Chinese Young Adults Using the Adult Eating Behavior Questionnaire: Factor Structure, Gender Invariance and Latent Mean Differences, and Associations With BMI. Assessment, 28(3), 877-889. https://doi.org/10.1177/1073191119864642

Herle, M., Smith, A., Bu, F., Steptoe, A., \& Fancourt, D. (2021). Trajectories of eating behavior during COVID-19 lockdown: Longitudinal analyses of 22,374 adults. Clinical Nutrition ESPEN, 42, 158-165. https://doi.org/10.1016/j.clnesp.2021.01.046

Hunot, C., Fildes, A., Croker, H., Llewellyn, C. H., Wardle, J., \& Beeken, R. J. (2016). Appetitive traits and relationships with BMI in adults: Development of the Adult Eating Behaviour Questionnaire. Appetite, 105, 356-363. https://doi.org/10.1016/j.appet.2016.05.024

Jenkins, F., \& Smith, J. (2021). Work-from-home during COVID-19: Accounting for the care economy to build back better. The Economic and Labour Relations Review, 32(1), 22-38. https://doi.org/10.1177/1035304620983608

Kabir, A., Miah, S., \& Islam, A. (2018). Factors influencing eating behavior and dietary intake among resident students in a public university in Bangladesh: A qualitative study. PloS one, 13(6), e0198801. https://doi.org/10.1371/journal.pone.0198801

Karl, K. A., Peluchette, J. V., \& Aghakhani, N. (2021). Virtual Work Meetings During the COVID-19 Pandemic: The Good, Bad, and Ugly. Small Group Research. https://doi.org/10.1177/10464964211015286

Kementerian Kesehatan RI. (2014). Peraturan Menteri Kesehatan Republik Indonesia Nomor 41 Tahun 2014 Tentang Pedoman Umum Gizi Seimbang. Retrieved from: http://hukor.kemkes.go.id/uploads/produk_hukum/PMK\%20No.\%2041\%20ttg\%20Pedoman\%20Gizi\%2 OSeimbang.pdf

Koh-Banerjee, Pauline \& Chu, Nain-Feng \& Spiegelman, Donna \& Rosner, Bernard \& Colditz, Graham \& Willett, Walter \& Rimm, Eric. (2003). Prospective study of the association of changes in dietary intake, physical activity, alcohol consumption, and smoking with 9-y gain in waist circumference among 16587 US men1-4. The American journal of clinical nutrition. 78. 719-27. https://doi.org/10.1093/ajcn/78.4.719

Mallan, K. M., Fildes, A., de la Piedad Garcia, X., Drzezdzon, J., Sampson, M., \& Llewellyn, C. (2017). Appetitive traits associated with higher and lower body mass index: evaluating the validity of the adult eating behaviour questionnaire in an Australian sample. The international journal of behavioral nutrition and physical activity, 14(1), 130. https://doi.org/10.1186/s12966-017-0587-7

Meiliana, M., Valentina, V., \& Retnaningsih, C. (2018). Hubungan Body Dissatisfaction dan Perilaku Diet pada Mahasiswa Universitas Katolik Soegijapranata Semarang. PRAXIS, 1(1), 49. https://doi.org/10.24167/praxis.v1i1.1628 
Mungkasa, O. (2020). Bekerja dari Rumah (Working From Home/WFH): Menuju Tatanan Baru Era Pandemi COVID 19. Jurnal Perencanaan Pembangunan: The Indonesian Journal of Development Planning, 4(2), 126-150. https://doi.org/10.36574/jpp.v4i2.119

Muchtadi, D. (2009). Pengantar Ilmu Gizi. Bandung: CV. Alfabeta.

Nurcahyo, F. (2011). Kaitan antara Obesitas dan Aktivitas Fisik. Medikora, 7 (1), 87-96. https://doi.org/10.21831/medikora.v0i1.4663

Ogden, Jane. (2010). The Psychology of Eating : from Healthy to Disordered Behavior, UK: Blackwell Publising.

Pujiati, Suci., (2010). Prevalensi dan faktor risiko obesitas sentral pada penduduk dewasa kota dan kabupaten Indonesia tahun 2007. Tesis. Program Pascasarjana Fakultas Kesehatan Masyarakat. Universitas Indonesia, Jakarta.

Razzoli, M., Pearson, C., Crow, S., \& Bartolomucci, A. (2017). Stress, overeating, and obesity: Insights from human studies and preclinical models. Neuroscience and biobehavioral reviews, $76(\mathrm{Pt} \mathrm{A}), 154-$ 162. https://doi.org/10.1016/j.neubiorev.2017.01.026

Roselly, N. A. A. (2008). Faktor-faktor yang berhubungan dengan Persen Lemak Tubuh pada Pria (40-55 tahun) di Kantor Direktorat Jenderal Zeni TNI-AD. Skripsi (tidak diterbitkan). Jakarta: FKM Universitas Indonesia. http://lib.ui.ac.id/detail?id=123964\&lokasi=lokal

Šmahel, D., Macháčková, H., Šmahelová, M., Čevelíček, M., Almenara, C. A., \& Holubčíková, J. (2018). Digital Technology, Eating Behaviors, and Eating Disorders. https://doi.org/10.1007/978-3-319-932217

Utama, L. J. (2020). Gaya Hidup Mayarakat Nusa Tenggara Timur Dalam Menghadapi Pandemi Corona Virus Disease 19 (Covid-19). An-Nadaa: Jurnal Kesehatan Masyarakat, 7 (1), 34-40.

von Eyben, F., Mouritsen, E., Holm, J. et al. (2003). Intra-abdominal obesity and metabolic risk factors: a study of young adults. International Journal, 27, 941-949. https://doi.org/10.1038/sj.ijo.0802309

Wehling, H., \& Lusher, J. M. (2019). Cognitive and Emotional Influences on Eating Behaviour: A Qualitative Perspective. Nutrition and Metabolic Insights. https://doi.org/10.1177/1178638819855936

Wenck, D.A, et al. (2000). Nutrition. A Prentice Hall Company. Reston, Virginia. WHO. (2000). The International Association for the Study of Obesity and The International Obesity Task Force.

WHO. (2021). Coronavirus. Retrieved from: https://www.who.int/health-topics/coronavirus\#tab=tab_2

Widiantini, W., \& Tafal, Z. (2014). Aktivitas Fisik, Stres, dan Obesitas pada Pegawai Negeri Sipil. Kesmas: Jurnal Kesehatan Masyarakat Nasional, 8 (7), 330-336. http://dx.doi.org/10.21109/kesmas.v0i0.374.g373

Wijayanti, A., Margawati, A., \& Wijayanti, H. S. (2019). Hubungan Stres, Perilaku Makan, Dan Asupan Zat Gizi Dengan Status Gizi Pada Mahasiswa Tingkat Akhir. Journal of Nutrition College, 8(1), 18. https://doi.org/10.14710/jnc.v8i1.23807

Wilson, E.D, K.H. Fisher, P.A. Garcia. (2000). Principles of Nutrition. John Wiley \& Sons.

Yong C, Liu H, Yang Q, Luo J, Ouyang Y, Sun M, Xi Y, Xiang C, Lin Q. (2021) The Relationship between Restrained Eating, Body Image, and Dietary Intake among University Students in China: A CrossSectional Study. Nutrients, 13(3):990. https://doi.org/10.3390/nu13030990 